\title{
PPARY as a sensor of lipase activity and a target for the lipase inhibitor orlistat
}

\author{
Harry Martin*, Tony K McGhie, Kerry Bentley-Hewitt and John Christeller
}

\begin{abstract}
A PPARy fluorescence polarization (FP) assay was used to measure the release of fatty acid products from triglyceride emulsions during digestion with pancreatic and yeast lipases in a real-time, homogenous assay. Using the same FP assay we show the anti-obesity drug Orlistat is a PPARy ligand with an $I_{50}$ of $2.84 \pm 0.16 \mu \mathrm{M}$. Analytical Mass Spectrometry confirms that Orlistat does not bind covalently to PPARY. The PPARY FP assay is shown to be a simple method for measuring real-time lipase activity using a number of triglyceride substrates including olive oil and grape seed oil emulsions. Incubation of Orlistat with the human intestinal epithelial cell line Caco-2, at concentrations of $1-100 \mu \mathrm{M}$, leads to induction of genes regulated by PPARY. At $100 \mu \mathrm{M}$ Orlistat, transcription of $\beta$-defensin 1 (hDB1) \& Adipose Differentiation Related Protein (ADRP) increase by up to 2.6 fold and 6.8 fold, respectively. Although at $1 \mu \mathrm{M}$ and $100 \mu \mathrm{M}$ Orlistat did not significantly increase defensin protein synthesis, at $10 \mu \mathrm{M}$ Orlistat induced a 1.5 fold increase in hDB1 protein secretion in the human colonic adenocarcinoma cell line HT-29. Thus Orlistat is similar to the anti-diabetic drug Rosiglitazone in its ability to induce defensin gene expression. The antimicrobial peptide $\beta$-defensin 1 protects against pathogenic micro-organisms in the gut and PPARY suppresses inflammatory gene expression. These may be beneficial side effects of Orlistat consumption on gut epithelial cells.
\end{abstract}

Keywords: PPARY, Orlistat, Xenical, Lipstatin, Lipase, Caco-2

\section{Background}

The PPARY agonist and anti-diabetic drug Rosiglitazone is known to induce expression of the human $\beta$-defensin 1 (hBD1) gene in human intestinal epithelial Caco-2 cells [1]. Defensins are cationic peptides expressed in phagocytic and epithelial cells that lyse micro-organisms by forming pores in their membranes. Deficiency of defensin expression is associated with colonisation of the gut with Candida albicans [2] and also with Crohn's disease [3]. Rosiglitazone has been used in the treatment of ulcerative colitis [4] but it has been associated with adverse cardiovascular effects in the treatment of type 2 diabetes [5].

The lipase inhibiting drug Orlistat is marketed by Roche under the trade name Xenical. It has a worldwide distribution and is used as an oral treatment for obesity [6]. Orlistat is also known as tetrahydrolipstatin and is a modified form of the streptomyces-derived lipase inhibitor lipstatin [7]. Orlistat is very hydrophobic: $(\log P \quad 7.6-8.1)$

\footnotetext{
* Correspondence: harry.martin@plantandfood.com

Food Innovation, the New Zealand Institute for Plant \& Food Research Ltd, Private Bag 11 600, Palmerston North 4442, New Zealand
}

and binds covalently to the active site serine of pancreatic lipase [8]. Only trace amounts of Orlistat are absorbed systemically and the drug remains almost entirely in the gut lumen [9]. However, Orlistat penetrates cell membranes sufficiently to have intracellular effects $[10,11]$. Liposarcoma cell growth is inhibited at a concentration of $20 \mu \mathrm{M}$ via inhibition of the intracellular enzyme, fatty acid synthase [12]. For this reason, Orlistat's anti-cancer properties are being explored in a number of cancerous tissues including colorectal [13], prostate [14] and leukemic cells [15]. The extreme hydrophobicity of Orlistat led us to speculate that it might also behave as a PPAR $\gamma$ agonist in the gut epithelium where, due to its retention in the gut lumen, the local Orlistat concentration is high.

PPARy binding activity was assayed by fluorescence polarization (FP) and mass spectrometry. Steady state mRNA levels of some PPAR $\gamma$ regulated genes in human Caco-2 epithelial cells were determined, including beta defensin-1, (hBD1), adipose differentiation related protein (ADRP) and PPAR $\gamma$ itself. In addition, due to the ability of PPAR $\gamma$ to bind a wide variety of fatty acids [16]
() Biomed Central

(c) 2013 Martin et al.; licensee BioMed Central Ltd. This is an Open Access article distributed under the terms of the Creative Commons Attribution License (http://creativecommons.org/licenses/by/2.0), which permits unrestricted use, distribution, and reproduction in any medium, provided the original work is properly cited. 
we explored the utility of the PPAR $\gamma$ FP assay as a realtime assay for lipase activity.

\section{Results}

Real time lipase assay using PPAR $\gamma$ fluorescence polarization method

Candida rugosa lipase and porcine pancreatic lipase were incubated at concentrations ranging from $30 \mu \mathrm{g} / \mathrm{mL}$ to $3.3 \mu \mathrm{g} / \mathrm{mL}$ with various triglyceride emulsions in the presence of the FP reagents and polarization readings were taken at 1-2 minute intervals for up to 30 minutes. The $\mathrm{PPAR} \gamma$ binding products released from the triglyceride emulsions were detected by the FP assay. Figure 1A shows the release of PPAR $\gamma$ binding products from digestion of varying concentrations of grape seed oil emulsion with Candida rugosa lipase. Figure 1B shows the release of PPAR $\gamma$ binding products from triolein using different concentrations of porcine pancreatic lipase. Figure $1 \mathrm{C}$ shows that release of PPARy binding ligands during the digestion of emulsions of three different substrates viz. grape seed oil, triolein, and olive oil. To confirm the utility of the FP assay as a lipase assay, the initial velocities $\left(\mathrm{V}_{\mathrm{o}}\right)$ of the enzyme rates (from Figure $1 \mathrm{~A}$ ) at the three different concentrations were estimated and shown to be linear over a 9-fold dilution range (Figures 1D and 1E). These experiments have been repeated at least three times and the results shown are representative of the assay data which are highly reproducible. Because the FP assay is carried out in a $20 \mu \mathrm{l}$ volume in a 384 well microplate, running replicates is simple and inexpensive.

\section{Measurement of Orlistat binding to PPARY by Fluorescence Polarization}

Although lipase activity is readily traced by the release of fatty acids from the triglyceride substrate, the use of PPAR $\gamma$ FP assay as a lipase assay has the limitation that lipase inhibitors will tend to bind directly to the PPAR $\gamma$ due to their hydrophobic nature. Figure 2 shows that Orlistat is a PPAR $\gamma$ ligand with an $\mathrm{IC}_{50}$ of $2.84 \mu \mathrm{M}, \pm 0.16$. By comparison, the PPAR $\gamma$ agonists Troglitazone and Rosiglitazone are shown with $\mathrm{IC}_{50}$ values of $1.27 \mu \mathrm{M} \pm 0.08$ and $0.37 \mu \mathrm{M} \pm 0.04$ respectively.

\section{Orlistat does not modify PPARy covalently}

Orlistat (Figure 2) forms a covalent adduct with pancreatic lipase and contains 3 carbonyl groups. Several carbonyl
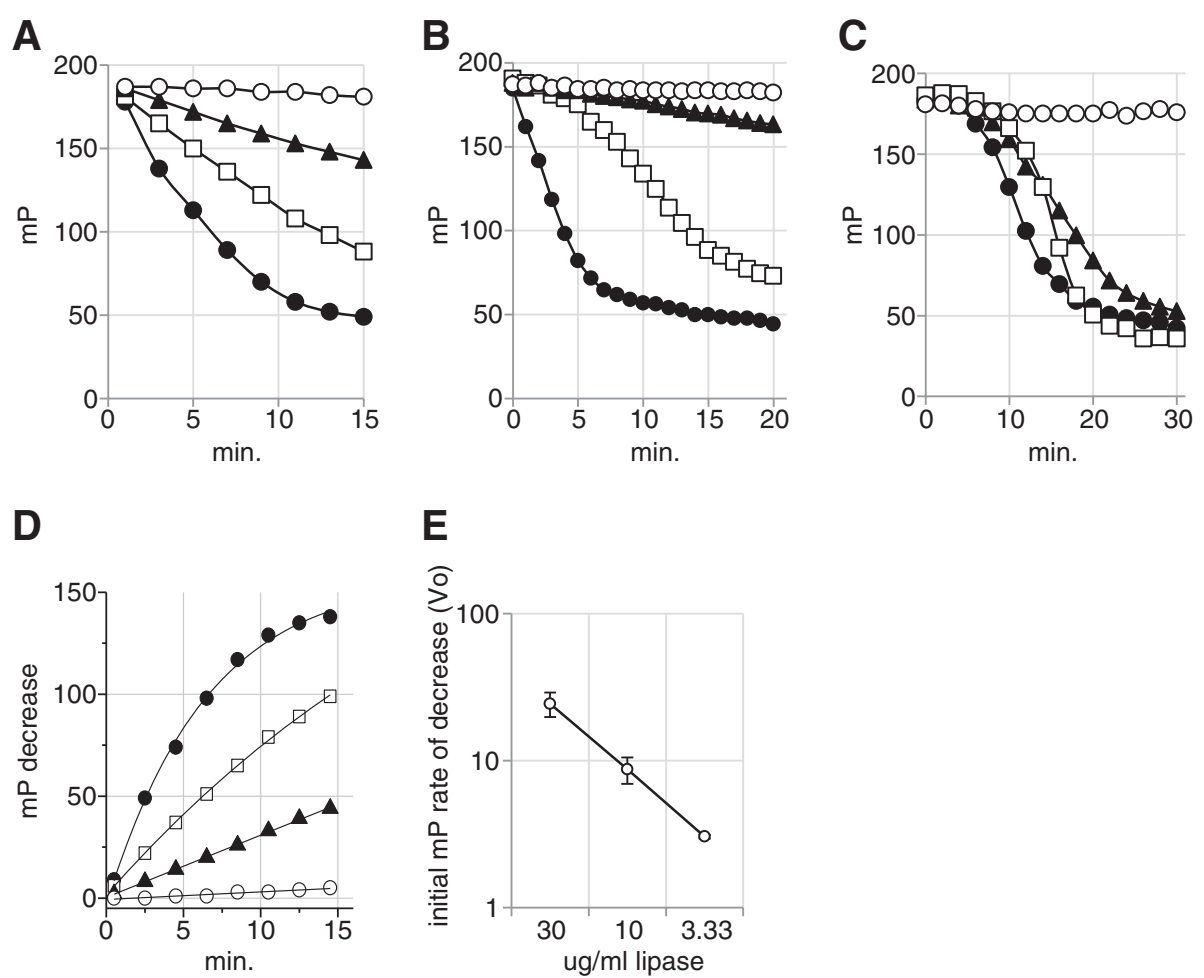

Figure 1 Time course of triglyceride emulsion digestion measured by a PPAR $\mathrm{FP}$ assay. A: Porcine pancreatic lipase digestion of $1.5 \mathrm{mg} / \mathrm{mL}$ triolein. Lipase concentration: $30 \mu \mathrm{g} / \mathrm{mL}(\bullet),(\square), \boldsymbol{\Delta} 3.3 \mu \mathrm{g} / \mathrm{mL}$, no enzyme (o). B: Candida rugosa lipase $(10 \mu \mathrm{g} / \mathrm{mL})$ digestion of grape seed oil emulsion. Substrate concentration: $1.5 \mathrm{mg} / \mathrm{mL}(\bullet), 0.15 \mathrm{mg} / \mathrm{mL}(\square),(\mathbf{\Lambda}) 0.015 \mathrm{mg} / \mathrm{mL}$, no substrate (o). C: Digestion of three different substrates each at $0.15 \mathrm{mg} / \mathrm{ml}$ with $10 \mathrm{\mu g} / \mathrm{ml}$ Candida rugosa lipase: grape seed oil $(\bullet)$, olive oil $(\square)$ and triolein $(\mathbf{\Lambda})$. D: Data from Figure 1 A plotted as increasing $\mathrm{mP}$ change and fitted for initial rate using MonoMolecular Curve fit to determine initial velocity. E: Initial velocities of lipase digestion reactions from Figure 1A/1D. 


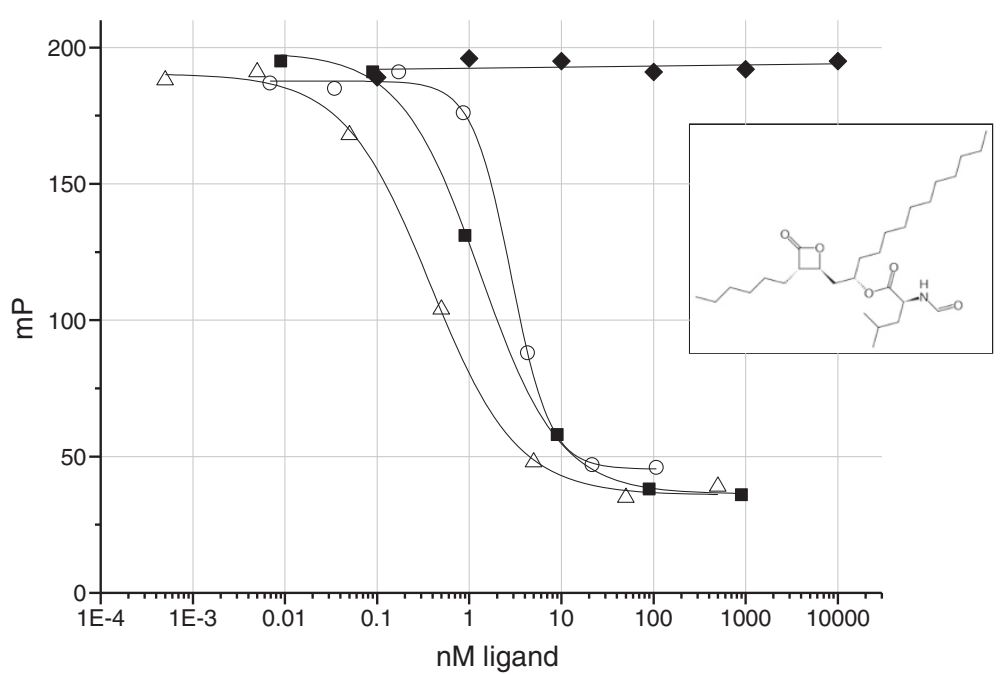

Figure 2 Dose response curves of Orlistat $(\circ)$, Troglitazone $(\square)$ and Rosiglitazone $(\Delta)$ and 5-aminosalicylic acid $(\diamond)$ in a PPARץ FP assay. The structure of Orlistat is shown inset.

containing fatty acids are known to bind covalently to the Cys285 in the ligand binding pocket of PPAR [17]. For this reason we investigated the possibility of covalent modification of PPAR $\gamma$ by Orlistat by mass spectrometry. Orlistat was incubated in ammonium acetate buffer $\mathrm{pH}$ 7.4 with PPAR $\gamma$ for 1 hour at room temperature and then analysed by LCMS. The sulfhydryl-specific reagent iodo-acetamido fluorescein (IAF) was included to confirm that this procedure was able to detect covalent modification of the PPARy. The molecular weight of the PPAR $\gamma$ was confirmed at $35,918 \mathrm{Da}$ and is consistent with data provided by the supplier. When IAF is added the molecular weight of PPAR $\gamma$ increased to $36,308 \mathrm{Da}$, an increase of $390 \mathrm{Da}$, consistent with the addition of IAF to a sulfhydryl group on the PPARy molecule. However, the molecular weight of PPARY remained at 35,319 Da when Orlistat was added, suggesting that Orlistat does not form covalent bonds with PPARY (Figure 3). In addition, two covalent PPARY ligands, Dithio-bis (2-nitrobenzoic acid) and GW9662, were also confirmed bind to PPARy irreversibly (data not shown).

\section{Orlistat induces hBD1, ADRP \& PPARy mRNA expression in Caco-2 cells}

Treatment of Caco-2 human intestinal epithelial cells with the PPARy activator Rosiglitazone is known to induce the induction and expression of the hBD1 gene and Adipose Differentiation Related Protein (ADRP). To determine whether Orlistat is also a PPAR $\gamma$ activator we treated Caco-2 cells with $100 \mu \mathrm{M}$ Orlistat or with $1 \mu \mathrm{M}$ Rosiglitazone for 24 hours before cells were harvested for analysis of gene induction. Following the initial observation that $100 \mu \mathrm{M}$ Orlistat induced hBD1 gene expression, the experiment was repeated using Orlistat at
100, 10 and $1 \mu \mathrm{M}$. The results of both experiments are shown in Figure 4. In the first experiment gene transcription of hBD1, PPAR $\gamma$, ADRP and were all significantly enhanced by treatment with $100 \mu \mathrm{M}$ Orlistat by 3.0, 6.0 and 5.7 fold respectively and also by Rosiglitazone, the positive control. In the second experiment, significant increases in defensin gene transcription occurred at all three concentrations of Orlistat. Even at $1 \mu \mathrm{M}$ Orlistat a 1.4 fold increase in defensin transcription was observed. In the second experiment, ADRP gene transcription was increased by around seven fold using Orlistat at $100 \mu \mathrm{M}$ and $10 \mu \mathrm{M}$ but no increase was observed at $1 \mathrm{uM}$ Orlistat. For reasons unknown, the PPARy gene induction seen in the first experiment was not observed in the second experiment.

\section{Orlistat induces hBD1 protein expression in expression in HT-29 cells}

To establish whether the Orlistat and Rosiglitazone induced $\beta$ defensin 1 mRNA expression was also associated with an increase in $\beta$ defensin1 protein synthesis, we first performed a sandwich ELISA on the tissue culture supernatants of $\mathrm{Caco} 2$ cells treated with Orlistat. We were unable to detect $\beta$ defensin 1 protein in the Caco2 supernatants although $\mathrm{Caco} 2$ are reported to synthesis $\beta$ defensin1 [18]. The related cell line HT-29 (a human colonic adenocarcinoma) was then used as an alternative to Caco2 (also human colorectal adenocarcinoma). Orlistat \& Rosiglitazone we tested at concentrations of 1,10 and $100 \mu \mathrm{M}$ for $24 \mathrm{~h}$ in culture. The supernatant was analysed by sandwich ELISA for hBD1 protein and the results are shown in Figure 5. Although the average defensin protein was increased at all concentrations of drug treatment, significant increases in defensin levels were only found at 

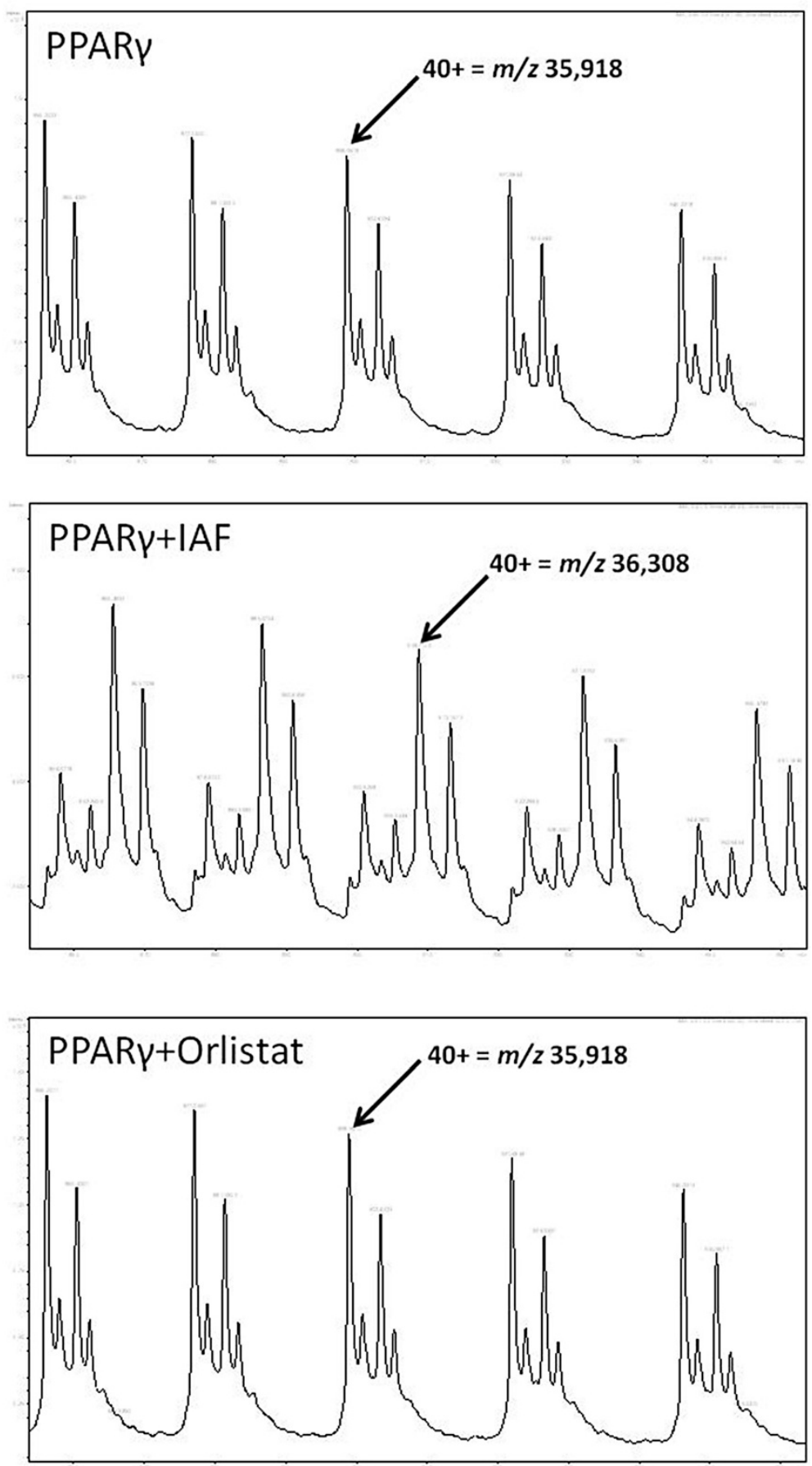

Figure 3 The molecular weights of PPARY and PPARY conjugates were measured by ESI-MS. The software package DataAnalysis (Bruker, Bremen, Germany) was used to average sample spectra and molecular weights calculated following charge deconvolution. The displayed mass spectra are of the molecular ion containing 40 positive charges and clearly show that the molecular weight of PPARY increased when IAF is bound, indicating covalent binding. Whereas, there is no change in the molecular weight of PPARY when Orlistat is bound, suggesting that the binding of PPARY to Orlistat is by non-covalent mechanisms. 


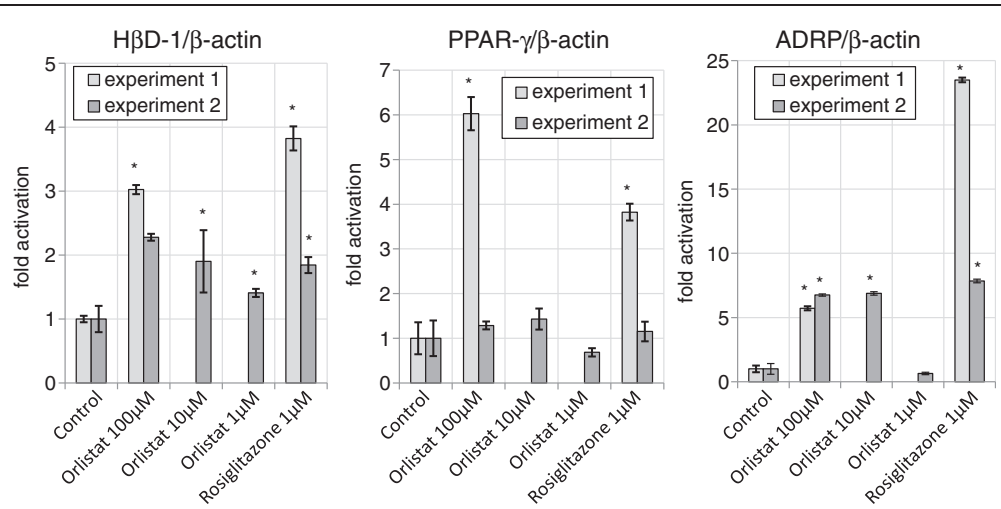

Figure 4 Relative gene expression of hBD1, PPARy and ADRP in Caco-2 cell following exposure to Orlistat, Rosiglitazone or DMSO control for $\mathbf{2 4} \mathbf{h}$. Individual results were normalised to $\beta$-actin. Each bar represent mean \pm SD $(n=3)$. Significant differences between treatment and control are shown as $*(p<0.05)$.

$10 \mu \mathrm{M}$ Orlistat ( 1.5 fold increase) \& $10 \mu \mathrm{M}$ Rosiglitazone $(\sim 2$ fold increase).

\section{Discussion}

The PPAR F FP assay provides a homogeneous and highthroughput method (Figure 1) for continuous monitoring of lipase reaction kinetics. The sensitivity of the assay is determined by the affinity of the fatty acid product for PPAR $\gamma$ ligand binding domain, which for many

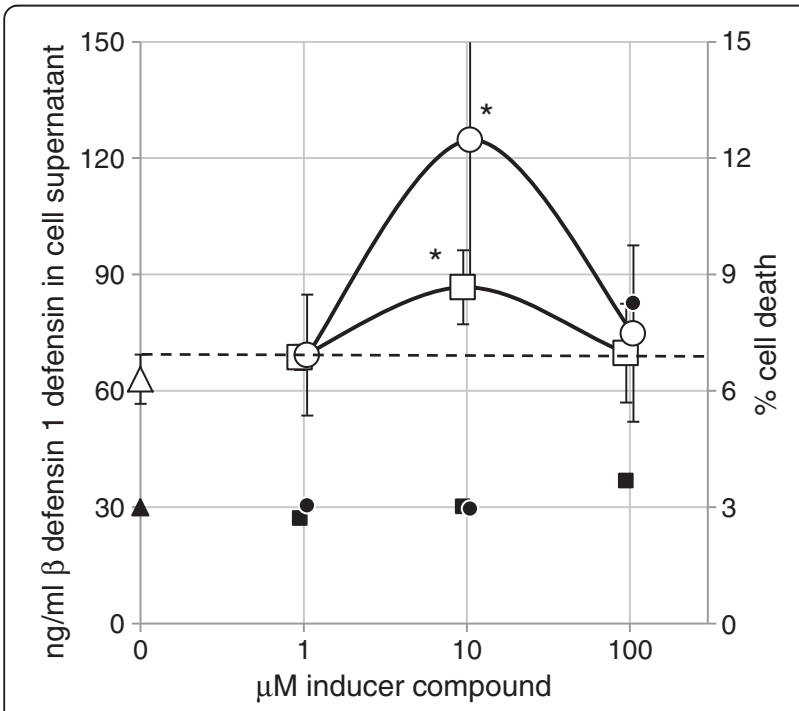

Figure 5 hBD1 protein expression in HT29 cell supernatants and cell death following $24 \mathrm{~h}$ exposure to Orlistat, Rosiglitazone and DMSO control. Each datapoint represents mean $\pm S D(n=3)$. Significant differences between treatment and control are shown as ${ }^{*}(p<0.05)$. The dashed line indicates the upper value of the error bar for the DMSO control sample. hBD1 protein in DMSO control cell supernatant $(\Delta)$, hBD1 protein in Rosiglitazone treated cell supernatant $(0), \mathrm{hBD} 1$ protein in Orlistat treated cell supernatant ( $\square$ ). Tissue culture percent cell death at $24 \mathrm{~h}$; DMSO control cells $(\mathbf{\Lambda})$, cell death in Rosiglitazone treated cells $(\bullet)$, cell death in Orlistat treated cells (-
PPARy ligands is in the low micromolar range. Since PPAR $\gamma$ is a non-selective binder of various fatty acids, the assay is will not distinguish different lipase products. The overlapping curves in Figure $1 \mathrm{C}$ may therefore reflect the formation of different products with different affinities for PPAR $\gamma$. Triolein yields oleic acid as a lipase digestion product whereas around $70 \%$ of the fatty acid content of grape seed oil is linoleic acid. The wide range of fatty acids which are PPAR ligands means that the assay can be applied to the analyses of many lipases \& substrates. At high concentrations of substrate (Figure 1A, $1 \mathrm{E})$, the rate of product formation is directly correlated with lipase concentration whereas at low substrate concentrations (Figure 1B, 1C) a distinct lag period is evident before product formation becomes detectable, giving the reaction curve a sigmoidal appearance. The reasons for the lag period are unclear at present and may reflect a combination of causes; the use of substrate at concentrations lower than the lipase $\mathrm{K}_{\mathrm{m}}$; partitioning of the emulsion substrate and enzyme at low substrate concentrations; a low threshold of product formation may be required before the fluorescent ligand can be displaced from the PPARy receptor in the FP reaction. Nonetheless, as Figure 1A shows, the FP assay is extremely simple and sensitive as a method detecting and for quantifying lipase in a sample. FP, as a ratiometric technique, is less sensitive to sample colour and opacity than direct fluorescence intensity methods. However, as the Orlistat data shows (Figure 2) the PPARy FP procedure is unlikely to permit the analysis of lipase inhibitors since their lipophilicity will tend to make them PPARy ligands. It is well known that cytosolic phospholipases initiate signal transduction pathways by releasing fatty acid signalling molecules from phospholipid membranes and that many of the phospholipase products are PPAR ligands. Thus, the in vitro generation of PPAR $\gamma$ ligands from lipase activity shown in Figure 1 is analogous to the situation in cells whereby 
phospholipase $A_{2}$ activation results in the generation of PPAR $\delta$ ligands and the subsequent expression of PPAR $\delta$ dependent genes [19].

The possibility of covalent bond formation between Orlistat \& PPAR $\gamma$ was investigated because Orlistat binds covalently to pancreatic and other lipases [8] and because keto-fatty acids are known to form a covalent bond with Cys285 in the ligand binding pocket of PPAR [17]. The mass spectrometry data shown in Figure 3 clearly demonstrated that Orlistat, which contains 3 carbonyls [7], does not bind covalently to PPAR $\gamma$ since no adduct was detectable by mass spectrometry.

The induction of beta defensin-1, and ADRP by Orlistat (Figure 4) in Caco-2 cells along with the direct binding of Orlistat to PPARY (Figure 2), is strong evidence that Orlistat is a PPAR $\gamma$ agonist since these genes are known to be induced by the PPAR $\gamma$ agonist drugs Troglitazone and Rosiglitazone [1,20]. In Figure 4, Orlistat was used at a concentration as high as $100 \mu \mathrm{M}$ because this concentration in the gut lumen would be achieved by the standard daily dose of $0.36 \mathrm{~g}$ Orlistat [21] coupled with almost complete retention of the drug in the in the gastrointestinal tract [9]. Although Orlistat will induce cell death in human colonic adenocarcinoma HT29 cells at a concentration of $100 \mu \mathrm{M}$ over 48 hours it does not induce cell death at $200 \mu \mathrm{M}$ over a period of 24 hours [13] and it is far less toxic to normal cells than to cancerous cells $[14,15]$. Furthermore, we see no evidence of cell death in our Caco-2 culture, for example, by detecting lower levels of control GAPDH RNA. Although Rosiglitazone was slightly toxic to HT-29 cells at $100 \mu \mathrm{M}$ (Figure 5) no evidence of toxicity was observed at $10 \mu \mathrm{M}$ at which a two-fold increase in $\beta$-defensin 1 protein was observed. Peyrin-Biroulet et al. (2010) has shown that Rosiglitazone induced hBD1 mRNA. Our data now confirms that hBD1 protein is also induced by Rosiglitazone. Although the Orlistat induced defensin protein is only increased by 1.5 fold at $10 \mu \mathrm{M}$, this may result in a significant physiological effect in patients in terms of pathogen resistance. A future study of the faecal hBD1 protein content in Orlistat patients might confirm a PPAR $\gamma$ mediated physiological benefit of Orlistat.

Orlistat suppresses the onset of type 2 diabetes [22] due the reduced calorific intake, and concomitant weight loss of patients. As a consequence of Orlistat's PPARy agonist activity, there may be local insulin sensitising effects in the gut epithelium and additional physiological responses including increased hBD1 and PPAR $\gamma$ transcription.

PPAR $\gamma$ activation is enhanced by the actions of cytosolic fatty acid binding proteins which deliver sparingly soluble fatty acid ligands to the nucleus [23]. This raises the question of whether Orlistat also binds to intracellular fatty acid binding proteins in gut epithelial cells and what the consequences of that putative binding might be. Orlistat consumption is well known to cause steatorrhea due to the arrival of undigested fat in the colon. Although Orlistat is an irreversible inhibitor of pancreatic lipase, it is a reversible inhibitor of certain bacterial lipases and not an inhibitor of a staphylococcal extracellular lipase [24]. Some colonic digestion of fats is likely to occur through bacterially-derived lipases in patients using Orlistat. The fatty acids produced in these circumstances may induce PPAR $\gamma$ dependent gene transcription in the epithelial cells of the intestine in the same way that Orlistat affects Caco- 2 cells. Thus, in addition to proapoptotic side effects of Orlistat in colorectal carcinoma cells [13], Orlistat may also induce anti-inflammatory genes in gut tissue mediated by its PPAR $\gamma$ agonist activity.

\section{Conclusions}

The widely used lipase inhibitor drug Orlistat binds reversibly to PPAR $\gamma$ with an $\mathrm{IC}_{50}$ of $2.8 \mu \mathrm{M}$. Orlistat acts on gut epithelial Caco- 2 cells as a PPAR $\gamma$ agonist and increases synthesis of human defensin $\beta 1$ and ADRP mRNA.

\section{Methods}

\section{Chemicals and materials}

Rosiglitazone, Troglitazone, 5-amino salicylic acid, GW9662 (a covalent binding PPAR $\gamma$ antagonist [25]), Orlistat, triolein and iodo-acetamido-fluorescein were supplied by SigmaAldrich. Grape seed oil and olive oil were commercial brands from local supermarkets in Palmerston North, New Zealand. LC-MS grade acetonitrile was from Thermo Scientific, methanol (ChromAR) was from Mallinckrodt Chemicals, and ethanol (95\%) was from LabServ.

\section{Fluorescence Polarization assay of PPARy ligands}

FP assays were performed on the Tecan Safire2 fluorescence microplate reader (Tecan, Austria) at $22^{\circ} \mathrm{C}$, in a volume of $20 \mu \mathrm{L}$ in Nunc 384 well, black, shallow microplates. The PPAR $\gamma$ (green) competitive binding assay (PolarScreen ${ }^{\mathrm{TM}}$ ) kit was supplied by Invitrogen

\begin{tabular}{|c|c|}
\hline Gene name /(genebank accession no.) & Primer and probe sequences \\
\hline \multirow{2}{*}{$\begin{array}{l}\text { GAPDH: Glyceraldehyde-3-phosphate } \\
\text { dehydrogenase (NM_002046.3) }\end{array}$} & F: AGCCACATCGCTCAGACAC \\
\hline & R: GCCCAATACGACCAAATCC \\
\hline \multirow[t]{2}{*}{ ACTB, $\beta$-actin (NM_005345.4) } & F: GGAGTCCTACGCCTTCAACA \\
\hline & R: CCAGCACCTTCTTCTTGTCG \\
\hline \multirow[t]{2}{*}{ hBD1, Human $\beta$ defensin 1 (X92744.1) } & F: TGTCTGAGATGGCCTCAG GT \\
\hline & R: GGGCAGGCAGAATAGAGACA \\
\hline \multirow{2}{*}{$\begin{array}{l}\text { ADRP, Adipose Differentiation Related } \\
\text { Protein (NM_001122.2) }\end{array}$} & F: TCAGCTCCATTCTACTGTTCACC \\
\hline & R: CCTGAATTTTCTGATTGGCACT \\
\hline \multirow[t]{2}{*}{ PPARy variant 1 (NM_138712.3) } & $\begin{array}{l}\text { F: GACAGGAAAGACAACAGAC } \\
\text { AAATC }\end{array}$ \\
\hline & R: GGGGTGATGTGTTTGAACTTG \\
\hline
\end{tabular}


Corporation, Carlsbad, CA, USA. For measurement of FP, excitation and emission wavelengths were set at $470 \mathrm{~nm}$ and $525 \mathrm{~nm}$. Sigmoidal and exponential curve fitting and $\mathrm{IC}_{50}$ and $\mathrm{V}_{\mathrm{o}}$ estimates were performed with Origin software (Origin-Lab, Northampton, MA, USA) using the logistic and MonoMolecular equations respectively. Data presented are representative of at least two independent experiments.

\begin{abstract}
Lipase assays
Porcine pancreatic lipase (L3126) and Candida rugosa lipase (L1754) was supplied by Sigma. Triolein, grape seed oil \& olive oil were used as triglyceride substrates for lipase assays. Lipase substrate was prepared according to the method of Nilsson-Ehle [26]. Briefly, substrate emulsions were prepared by mixing $240 \mathrm{mg}$ triglyceride substrate and $40 \mathrm{mg}$ whey protein (WP1485) in $10 \mathrm{~g}$ glycerol. $200 \mu \mathrm{L}$ of this stock solution was added to $800 \mu \mathrm{L} 50 \mathrm{mM}$ Hepes buffer pH7.5 which was sonicated for six periods of $5 \mathrm{sec}$ at 6 watts for each $\mathrm{mL}$ of assay mix. For FP assays, the substrate emulsions were diluted in Invitrogen FP PPAR $\gamma$ assay buffer to a final concentration of $0.15 \mathrm{mg} / \mathrm{mL}$ triglyceride and digested with lipase for 30 minutes at $22^{\circ} \mathrm{C}$ in volumes of $20 \mu \mathrm{L}$. During the digestion period, FP readings were taken at 1 or 2 minute intervals.
\end{abstract}

\section{LC-QTOF-HRMS}

The LC-MS system was composed of a Dionex Ultimate ${ }^{\circledR}$ 3000 Rapid Separation LC system and a micrOTOF QII mass spectrometer (Bruker Daltonics, Bremen, Germany) and was operating in positive mode with an electrospray ionization source. The LC system contained a SRD-3400 solvent rack/degasser, HPR-3400RS binary pump, WPS3000RS thermostated autosampler, and a TCC-3000RS thermostated column compartment. The analytical column was a Zorbax ${ }^{\text {TM }}$ SB-C18 $2.1 \times 100 \mathrm{~mm}, 1.8 \mu \mathrm{m}$ (Agilent, Melbourne, Australia) maintained at $50^{\circ} \mathrm{C}$ and operated in gradient mode. Solvents were $\mathrm{A}=0.5 \%$ formic acid, and $B=100 \%$ acetonitrile at a flow of $400 \mu \mathrm{L} / \mathrm{min}$. The gradient was: $70 \% \mathrm{~A}, 30 \% \mathrm{~B}, 0-0.5 \mathrm{~min}$; linear gradient to $45 \% \mathrm{~A}, 55 \% \mathrm{~B}, 0.5-25 \mathrm{~min}$; linear gradient to $2 \% \mathrm{~A}, 98 \% \mathrm{~B}$, 25-45 min; composition held at 2\%A, 98\% B, 45-50 min; linear gradient to $70 \% \mathrm{~A}, 30 \% \mathrm{~B}, 50-50.2 \mathrm{~min}$; to return to the initial conditions before another sample injection at $54 \mathrm{~min}$. The injection volume for samples and standards was $2 \mu \mathrm{L}$. The micrOTOF QII source parameters were: temperature $200^{\circ} \mathrm{C}$; drying N2 flow $8 \mathrm{~L} / \mathrm{min}$; nebulizer N2 $4.0 \mathrm{bar}$, endplate offset $-500 \mathrm{~V}$, capillary voltage $-4000 \mathrm{~V}$; mass range $100-1500 \mathrm{Da}$, acquired at 2 scans/s. Postacquisition internal mass calibration used sodium formate clusters with the sodium formate delivered by a syringe pump at the start of each chromatographic analysis.

\section{Tissue culture}

Caco-2 cells and HT-29 cells were cultured in DMEM supplemented with $5 \%$ Foetal bovine serum, glutamine \& antibiotics at $37^{\circ} \mathrm{C}, 5 \% \mathrm{CO}_{2}$. Test compounds in DMSO were tested in triplicate by addition of $1 \mu \mathrm{l}$ of test compound to $1 \mathrm{ml}$ cell culture for $24 \mathrm{~h}$.

\section{Real-Time RT-PCR}

Total RNA was extracted by the use of High Pure RNA Isolation Kit and reverse transcription performed using Transcriptor First Strand cDNA Synthesis kit with oligo$\mathrm{dT}$ primed reactions, both according to manufacturer's instructions (Roche Diagnostics, New Zealand). Primers and primer-dual hybridisation probe combinations (Roche Diagnostics, Germany-Table 1) were designed online using the Universal probe library system assay design centre (Roche Applied Science). The RT-qPCR assay was performed using the Lightcycler ${ }^{\oplus} 480$ system (Roche Diagnostics, Germany) with three reactions (technical replicates) for each sample. Real-time PCR parameters are as follows: 10 minutes (0:10:00) pre-incubation at $95^{\circ} \mathrm{C}$, 40 cycles of amplification from $95^{\circ} \mathrm{C}(0: 00: 10)$, to $58^{\circ} \mathrm{C}$ (0:00:20), to $72^{\circ} \mathrm{C}$ (0:00:01), followed by cooling at $40^{\circ} \mathrm{C}$ $(0: 00: 10)$. Results were relative to the expression of glyceraldehyde-3-phosphate dehydrogenase and $\beta$-actin, however the latter produced most consistent expression between samples and was used as the reference gene to calculate final relative expression.

\section{Statistical analysis}

Quantitative RT-PCR results were analysed using inbuilt relative quantification software (Light -Cycler 480 software version 1.0), using the standard curve for both target and reference (ACTB) gene and the software then determined the target to reference ratio.

\section{$\beta$-defensin ELISA}

$24 \mathrm{~h}$ tissue culture supernatants were analysed in triplicate for human- $\beta$ defensin 1 using a commercial sandwich ELISA kit supplied by Genway, San Diego.

\section{Competing interests \\ None of the authors have a financial conflict of interest in regards to the materials included in this paper.}

\section{Authors' contributions}

Orlistat, Lipases and triglyceride substrates were supplied \& prepared by JC. Fluorescence Polarization assays were performed by HM. Mass spectrometry was carried out by TMCG. RT-PCR \& defensin ELISAs were performed by KBH. All authors read and approved the final manuscript.

\section{Acknowledgements}

This work was supported by Nutrigenomics New Zealand, a collaboration between AgResearch Ltd., Plant and Food Research, and The University of Auckland with funding through the New Zealand Ministry of Science and Innovation (MSI).

Harry Martin was funded by Nutrigenomics New Zealand. 
Received: 6 March 2013 Accepted: 31 March 2013

Published: 8 April 2013

\section{References}

1. Peyrin-Biroulet L, Beisner J, Wang GX, Nuding S, Oommen ST, Kelly D, Parmentier-Decruca E, Dessein R, Merour E, Chavatte $P$, et al: Peroxisome proliferator-activated receptor gamma activation is required for maintenance of innate antimicrobial immunity in the colon. Proc Natl Acad Sci USA 2010, 107:8772-8777.

2. Jurevic RJ, Bai M, Chadwick RB, White TC, Dale BA: Single-nucleotide Polymorphisms (SNPS) in human beta-defensin 1: High-throughput SNP assays and association with Candida carriage in type I diabetics and nondiabetic controls. J Clin Microbiol 2003, 41:90-96.

3. Kocsis AK, Lakatos PL, Somogyvari F, Fuszek P, Papp J, Fischer S, Szamosi T, Lakatos L, Kovacs A, Hofner P, Mandi Y: Association of beta-defensin 1 single nucleotide polymorphisms with Crohn's disease. Scand J Gastroenterol 2008, 43:299-307.

4. Lewis JD, Lichtenstein GR, Deren JJ, Sands BE, Hanauer SB, Katz JA, Lashner $\mathrm{B}$, Present $\mathrm{DH}$, Chuai S, Ellenbergr JH, et al: Rosiglitazone for active ulcerative colitis: A randomized placebo-controlled trial. Gastroenterology 2008, 134:688-695

5. Nissen SE, Wolski K: Effect of Rosiglitazone on the risk of myocardial infarction and death from cardiovascular causes. N Engl J Med 2007, 356:2457-2471.

6. Drent ML, Vanderveen EA: Lipase Inhibition - a Novel Concept in the Treatment of Obesity. Int J Obes 1993, 17:241-244.

7. Barbier P, Schneider F: Syntheses of Tetrahydrolipstatin and AbsoluteConfiguration of Tetrahydrolipstatin and Lipstatin. Helvetica Chimica Acta 1987, 70:196-202.

8. Hadvary P, Sidler W, Meister W, Vetter W, Wolfer H: The Lipase Inhibitor Tetrahydrolipstatin Binds Covalently to the Putative Active-Site Serine of Pancreatic Lipase. J Biol Chem 1991, 266:2021-2027.

9. Padwal RS, Majumdar SR: Drug treatments for obesity: Orlistat, sibutramine, and rimonabant. Lancet 2007, 369:71-77.

10. Chuang M, Severson DL: Metabolic fate of exogenous diacylglycerols in A10 smooth muscle cells. Biochim Biophys Acta Lipids and Lipid Metab 1998, 1390:149-159.

11. Ko J, Small DM: Behavior of tetrahydrolipstatin in biological model membranes and emulsions. J Lipid Res 1997, 38:1544-1552.

12. Olsen AM, Eisenberg BL, Kuemmerle NB, Flanagan AJ, Morganelli PM, Lombardo PS, Swinnen JV, Kinlaw WB: Fatty acid synthesis is a therapeutic target in human liposarcoma. Int J Oncol 2010, 36:1309-1314.

13. Chuang $H-Y$, Chang $Y-F$, Hwang J-J: Antitumor effect of Orlistat, a fatty acid synthase inhibitor, is via activation of caspase-3 on human colorectal carcinoma-bearing animal. Biomed Pharmacother 2011, 65:286-292.

14. Kridel SJ, Axelrod F, Rozenkrantz N, Smith JW: Orlistat is a novel inhibitor of fatty acid synthase with antitumor activity. Cancer Res 2004, 64:2070-2075

15. Pallasch CP, Schwamb J, Koenigs S, Schulz A, Debey S, Kofler D, Schultze JL, Hallek M, Ultsch A, Wendtner CM: Targeting lipid metabolism by the lipoprotein lipase inhibitor Orlistat results in apoptosis of B-cell chronic lymphocytic leukemia cells. Leukemia 2008, 22:585-592.

16. Schopfer FJ, Cole MP, Groeger AL, Chen CS, Khoo NKH, Woodcock SR, Golin-Bisello F, Motanya UN, Li Y, Zhang JF, et al: Covalent Peroxisome Proliferator-activated Receptor gamma Adduction by Nitro-fatty Acids selective ligand activity and anti-diabetic signaling actions. J Biol Chem 2010, 285:12321-12333.

17. Itoh T, Fairall L, Amin K, Inaba Y, Szanto A, Balint BL, Nagy L, Yamamoto K, Schwabe JWR: Structural basis for the activation of PPAR gamma by oxidized fatty acids. Nat Struct Mol Biol 2008, 15:924-931.

18. O'Neil DA, Porter EM, Elewaut D, Anderson GM, Eckmann L, Ganz T, Kagnoff MF: Expression and regulation of the human beta-defensins hBD-1 and hBD-2 in intestinal epithelium. J Immunol 1999, 163:6718-6724.

19. Xu LH, Han C, Lim K, Wu T: Cross-talk between peroxisome proliferatoractivated receptor delta and cytosolic phospholipase $\mathrm{A} 2$ alpha/ cyclooxygenase-2/prostaglandin E-2 signaling pathways in human hepatocellular carcinoma cells. Cancer Res 2006, 66:11859-11868.

20. Rogue A, Spire C, Brun M, Claude N, Guillouzo A: Gene Expression Changes Induced by PPAR Gamma Agonists in Animal and Human Liver. Ppar Res 2010. doi:Article ID 325183, 10.1155/2010/325183.
21. Poston WCS, Reeves RS, Haddock CK, Stormer S, Balasubramanyam A, Satterwhite O, Taylor JE, Foreyt JP: Weight loss in obese Mexican Americans treated for 1-year with Orlistat and lifestyle modification. Int J Obes 2003, 27:1486-1493.

22. Torgerson JS, Hauptman J, Boldrin MN, Sjostrom L: XENical in the Prevention of Diabetes in Obese Subjects (XENDOS) study: a randomized study of Orlistat as an adjunct to lifestyle changes for the prevention of type 2 diabetes in obese patients. Diabetes Care 2004, 27:856-856.

23. Tan NS, Shaw NS, Vinckenbosch N, Liu P, Yasmin R, Desvergne B, Wahli W, Noy N: Selective cooperation between fatty acid binding proteins and peroxisome proliferator-activated receptors in regulating transcription. Mol Cell Biol 2002, 22:5114-5127.

24. Borgstrom B: Mode of Action of Tetrahydrolipstatin - a Derivative of the Naturally-Occurring Lipase Inhibitor Lipstatin. Biochim Biophys Acta 1988, 962:308-316.

25. Leesnitzer LM, Parks DJ, Bledsoe RK, Cobb JE, Collins JL, Consler TG, Davis $R G$, Hull-Ryde EA, Lenhard JM, Patel $L$, et al: Functional consequences of cysteine modification in the ligand binding sites of peroxisome proliferator activated receptors by GW9662. Biochemistry 2002, 41:6640-6650.

26. Nilsson-Ehle P, Schotz MC: A stable, radioactive substrate emulsion for assay of lipoprotein lipase. J Lipid Res 1976, 17:536.

\section{doi:10.1186/1476-511X-12-48}

Cite this article as: Martin et al:: PPARY as a sensor of lipase activity and a target for the lipase inhibitor orlistat. Lipids in Health and Disease 2013 $12: 48$.

\section{Submit your next manuscript to BioMed Central and take full advantage of:}

- Convenient online submission

- Thorough peer review

- No space constraints or color figure charges

- Immediate publication on acceptance

- Inclusion in PubMed, CAS, Scopus and Google Scholar

- Research which is freely available for redistribution

Submit your manuscript at www.biomedcentral.com/submit
C Biomed Central 